\title{
Growth Performance and Plasma Metabolites of Grazing Beef Cattle Backgrounded on Buffel or Buffel-Desmanthus Mixed Pastures
}

\author{
Felista W. Mwangi ${ }^{1}$, Christopher P. Gardiner ${ }^{1}$, Glen Walker ${ }^{1}$, Trevor J. Hall ${ }^{2}$, Bunmi S. Malau-Aduli ${ }^{3}{ }^{1}$, \\ Robert T. Kinobe ${ }^{1}(\mathbb{D}$ and Aduli E. O. Malau-Aduli $1, * \mathbb{C}$
}

1 Animal Genetics and Nutrition, Veterinary Sciences Discipline, College of Public Health, Medical and Veterinary Sciences, Division of Tropical Health and Medicine, James Cook University, Townsville, QLD 4811, Australia; felista.mwangi@my.jcu.edu.au (F.W.M.); christopher.gardiner@jcu.edu.au (C.P.G.); glen.walker@jcu.edu.au (G.W.); robert.kinobe@jcu.edu.au (R.T.K.)

2 Hallmark Rural Consulting, 75 Love Road, Vale View, QLD 4352, Australia; trevhall02@yahoo.com.au

3 College of Medicine and Dentistry, Division of Tropical Health and Medicine, James Cook University, Townsville, QLD 4811, Australia; bunmi.malauaduli@jcu.edu.au

* Correspondence: aduli.malauaduli@jcu.edu.au; Tel.: +61-747-815-339

\section{check for} updates

Citation: Mwangi, F.W.; Gardiner, C.P.; Walker, G.; Hall, T.J.;

Malau-Aduli, B.S.; Kinobe, R.T.;

Malau-Aduli, A.E.O. Growth

Performance and Plasma Metabolites of Grazing Beef Cattle Backgrounded on Buffel or Buffel-Desmanthus Mixed Pastures. Animals 2021, 11, 2355.

https://doi.org/10.3390/

ani11082355

Academic Editor: Igino Andrighetto

Received: 28 June 2021

Accepted: 6 August 2021

Published: 9 August 2021

Publisher's Note: MDPI stays neutral with regard to jurisdictional claims in published maps and institutional affiliations.

Copyright: (c) 2021 by the authors. Licensee MDPI, Basel, Switzerland. This article is an open access article distributed under the terms and conditions of the Creative Commons Attribution (CC BY) license (https:/ / creativecommons.org/licenses/by/ $4.0 /)$.
Simple Summary: Pasture quality and digestibility decline during the dry season resulting in weight loss or marginal weight gains of grazing cattle in the seasonally dry subtropics of northern Australia. Oversowing grass with legume pastures has shown potential to improve pasture quality and cattle weight gain. This study aimed to evaluate the change in steers' weight gain and plasma metabolites in response to grazing buffel grass pastures oversown with Desmanthus spp. (Desmanthus), a tropical legume adapted to cracking clay soils, compared to buffel-grass-only pastures. Results showed that Desmanthus at a low botanical composition had no effect on weight gain and plasma metabolites, although pasture yield and stocking rate were $443 \mathrm{~kg} / \mathrm{ha}$ and $9.5 \%$ higher, respectively. Since the productivity of grazing systems depends on cattle annual weight gain and stocking rate, the practical implication of this study is that Desmanthus may improve the profitability of beef production in the dry tropics of northern Australia by improving pasture-carrying capacity with no adverse effect on cattle health status and growth performance.

Abstract: Dietary crude protein and dry matter digestibility are among the major factors limiting feed intake and weight gain of cattle grazing native and improved pastures in the subtropics of Northern Australia during the dry season. Incorporating a suitable legume into grasses improves pasture quality and cattle weight gain, but only a limited number of legume pastures can establish and persist in cracking clay soils. This study aimed to evaluate the effect of Desmanthus inclusion in buffel grass (Cenchrus ciliaris) pastures on the plasma metabolite profile and growth performance of grazing beef cattle during the dry season. We hypothesised that backgrounding steers on buffel grass-Desmanthus mixed pastures would elicit significant changes in plasma glucose, bilirubin, creatinine, non-esterified fatty acids and $\beta$-hydroxybutyrate, resulting in higher liveweight gains than in steers on buffel grass only pastures. Four hundred tropical composite steers were assigned to buffel grass only $(n=200)$ or buffel grass oversown with Desmanthus (11.5\% initial sward dry matter) pastures $(n=200)$ and grazed for 147 days during the dry season. Desmanthus accounted for $6.2 \%$ sward dry matter at the end of grazing period. Plasma metabolites results showed that changes in $\beta$-hydroxybutyrate, creatinine, bilirubin, glucose and non-esterified fatty acids were within the expected normal range for all the steers, indicating that with or without Desmanthus inclusion in the diet of grazing steers, animal health status was not compromised. It was also evident that Desmanthus inclusion in buffel grass pastures had no impact on the plasma metabolite profile, liveweight and daily weight gain of grazing steers. Therefore, our tested hypothesis of higher changes in plasma metabolite profile and higher liveweight gains due to backgrounding on low-level buffel grass-Desmanthus mixed pastures does not hold. 
Keywords: plasma metabolites; buffel grass; tropical beef cattle; growth performance; tropical pastures; backgrounding; legumes; liveweight

\section{Introduction}

Livestock production in the tropics plays a significant role in terms of animal numbers, total products output and employment globally [1], but beef cattle production measured as annual live weight gain is low from tropical pastures compared to temperate pastures [2]. In northern Australia's dry tropical environment, beef cattle rely mainly on extensive grazing of unimproved native pastures dominated by $\mathrm{C} 4$ grasses with limited use of exotic pasture species [3-5]. The dry tropics are characterized by a distinct wet and dry season, both of which vary greatly in length; for instance, the dry season varies from four to nine months of the year [6]. As a result, the quantity and nutritive value of pastures vary widely throughout the year. Pasture growth takes place in the wet season of November to April, resulting in increased green herbage mass, crude protein content and dry matter digestibility. Towards the end of wet/growing season and during the dry season, pasture senescence reduces green herbage mass, crude protein content, dry matter digestibility and, consequently, cattle dry matter intake [7,8]. Thus, high cattle weight gains are observed during the wet season, which can exceed a kilogram per day [6], but reduces in the dry season, sometimes resulting in weight loss [9].

The importance of tropical legume pastures to improve beef production has long been established [10-12]. The integration of legumes into grass pastures increases protein and digestible energy intake resulting in improved cattle growth rate and reduced age at slaughter [9]. In northern Australia, pasture legumes came to general use over five decades ago [13] and legumes of the genus Stylosanthes (Stylo) have a significant economic impact on light soils of tropical northern Australia [14,15], but there was no suitable legume pasture for the regions with cracking clay (vertosol) soils until recently [16]. Vertosol soils play a significant role in northern Australian beef cattle production, particularly in the State of Queensland, which accounts for $46 \%$ of the Australian beef cattle herd [17]. Vertosol soils also occupy $28 \%$ of the total area [18] and account for over 3.2 million ha of land [19] within the subcoastal north-eastern Australia between latitudes $16^{\circ} \mathrm{S}$ and $25^{\circ} \mathrm{S}$ [15].

Legumes of the genus Desmanthus spp. (referred to as Desmanthus henceforth) can be utilised for pasture improvement. Desmanthus persists on cracking clay soils, grows in a wide range of rainfall zones, survives in as low as $400 \mathrm{~mm}$ of rainfall per annum, is highly productive $[20,21]$ and decreases methane emissions in beef cattle $[22,23]$. Hill et al. [24] reported an increase in the use of legume-based pastures for livestock production in Australia due to financial pressure that has prompted the need for a more cost-effective protein source. As a result, over 35,000 ha of the three commercially available Desmanthus species (D. bicornutus, D. leptophyllus and D. virgatus), have been established across many regions of Australia including Queensland, Northern Territory and northern New South Wales since 2012 [25]. However, only limited literature exists on the effect of Desmanthus pasture grazing on animal growth performance and none on plasma metabolites profile. A study on the effect of Desmanthus on steer performance reported that steers grazing Desmanthus/buffel grass pastures were $30 \mathrm{~kg}$ heavier than those grazing buffel-grass-only pastures after 90 days [26]. Goats fed Brachiaria mulato (Mulato) grass and supplemented with Desmanthus at $27 \%$ dry matter intake (DMI) gained $17 \mathrm{~g} /$ day more than those fed Mulato grass only [27]. Supplementing sheep fed Mitchell grass (Astrebla spp.) basal diet with D. leptophyllus, D. pubescens or D. virgatus hay reduced weight loss from $5.83 \mathrm{~kg} / \mathrm{hd}$ in control to between 1.33 and $2.33 \mathrm{~kg} / \mathrm{hd}$ [28]. In contrast, growing goats fed Sorghum bicolor (Sudan grass) and supplemented with D. bicornutus at 40\% DMI gained $16 \mathrm{~g} /$ day less weight compared to those supplemented with Leucaena, alfalfa and lablab [29]. These studies were either indoor trials or conducted in small paddocks, which do not represent 
the extensive grazing systems of northern Australia. In addition, pasture legume levels of $27-40 \%$ used in these indoor studies may not be achieved.

Liveweight and body condition scores are traditional routine methods used to evaluate cattle nutritional status because they are quicker to perform and requires less expertise, but they are associated with several limitations [30]. Bodyweight evaluates nutritional status by measuring growth as a function of cell enlargement, cell multiplication and incorporation of constituents from the environment, for example, in apatite deposition [31]. Change in body weight can result from tissue hydration, change in gut and bladder fill, pregnancy and parturition rather than change in body fat or protein content [32]. Body condition score assesses the animal nutritional status over time as a function of the level of fatness on the animal [33], but is less reliable due to the general subjective nature [30]. Plasma metabolites, on the other hand, provide an integrated index of nutrient supply adequacy in relation to nutrient utilisation [34] and provide an immediate indication of the animal's present nutritional status [35]. Animals grazing low-quality pastures during the dry season mobilize fatty acids from the adipose tissue as a long-term response to the negative energy balance resulting in elevated NEFA and BHB [36,37]. Supplementing animals fed low-quality grass diet with legumes improves their nutritional plane, thus minimizing catabolism to encourage anabolic processes. In addition to improving the nutritional plane of animals, legume supplementation improves their health status. Supplementing grass-fed sheep with Moringa oleifera was reported to increase blood glucose and immunoglobulin A levels [10]. In another study, calves supplemented with alfalfa hay had lower plasma BHB compared to their unsupplemented counterparts [38]. Although numerous reports on the effect of dietary legume supplementation on blood parameters in dairy cows exist [39,40], little information is reported on beef cattle [41]. Therefore, the primary aim of this study was to evaluate the growth performance and plasma metabolites of beef cattle backgrounded (the grazing period between weaning and finishing) on buffel grass pasture oversown with Desmanthus during the dry season. We hypothesised that backgrounding steers on lowlevel buffel grass-Desmanthus mixed pastures would elicit significant changes in plasma glucose, bilirubin, creatinine, non-esterified fatty acids and $\beta$-hydroxybutyrate, resulting in higher liveweight gains than in steers on buffel-grass-only pastures.

\section{Materials and Methods}

All procedures in this study followed the James Cook University Animal Ethics Committee approved guidelines (Approval Number 2639) in accordance with the Australian code of practice for the care and use of animals for scientific purposes [42].

\subsection{Study Site}

This dry season on-farm study from 9th July to 3rd December 2019 was carried out at Cungelella, a commercial beef pastoral property in central Queensland $\left(24^{\circ} 41^{\prime} \mathrm{S}, 147^{\circ} 10^{\prime} \mathrm{E}\right)$, Australia. The mean annual rainfall of the farm is $598 \mathrm{~mm}$ with mean minimum and maximum temperatures of $12.7^{\circ} \mathrm{C}$ and $29.1^{\circ} \mathrm{C}$, respectively. The soils are typically low in nitrogen and phosphorus, alkaline and contain moderate to high clay content [43]. Two buffel grass-dominated paddocks were assigned as buffel grass ( $575 \mathrm{ha}$ ) and mixed buffel grass-Desmanthus (520 ha) pastures. Desmanthus was sown in March 2018 in established buffel grass pastures. The paddock was sprayed with glyphosate-based herbicide (Roundup; Monsanto, Kilda Road, Melbourne, Australia) at the rate of 3 in $37 \mathrm{~L}(v / v)$ of water per ha and then Desmanthus seed was aerial-sown at the rate of $3-5 \mathrm{~kg} / \mathrm{ha}$. Desmanthus (Progardes ${ }^{\circledR}$; Agrimix Pastures Pty Ltd., Ferny Hills DC, QLD, Australia) was a blend of D. leptophyllus, D. virgatus and D. bicornutus (cultivars JCU2, JCU4, JCU5 and JCU7), which range from early, medium to late maturing species $[44,45]$. The pastures were not fertilised. After self-seeding re-establishment of buffel grass, both paddocks were grazed heavily in 2018 to control competition and for Desmanthus to establish well [46]. The paddocks were destocked in September 2019, before the start of the wet season that usually starts in November. 


\subsection{Animal Management}

Four hundred 15-18-month-old weaned tropical composite steers of crossbred Bos indicus and Bos taurus genotypes, weighing $320 \pm 21 \mathrm{~kg}$ as the initial average liveweight, were utilised in this set-stocked 147-day grazing trial. Prior to the experiment, the steers were grazing on buffel grass-dominated pastures. Experimental steers were randomly assigned to either of the two pastures, buffel grass only $(n=200)$ or mixed buffel grass-Desmanthus pastures $(n=200)$ at 2.87 and $2.60 \mathrm{ha}$ / steer stocking rate, respectively, based on the farm manager's long knowledge of the paddocks' carrying capacity and remained constant throughout the trial period. Steers were not supplemented throughout backgrounding and were weighed on days $0,49,79$ and 147 after the onset of grazing. Steers were brought from the paddocks at 09:00 h, left in the holding yards for one hour and weighed between 10:00 $\mathrm{h}$ and 14:00 $\mathrm{h}$. Unfasted weights were recorded automatically (Gallagher 65 Scanlon Drive, Epping, Victoria 3076, Australia) and the average daily weight gain (ADG) was calculated by regression using the four weigh points. An a priori power analysis using G-Power was conducted to determine the appropriate sample size (Figure 1). A total sample size of 50 steers was required to achieve statistical power of $80 \%$ with a critical F-value of 4.0 for a large effect size and a significance level of 0.05 . Therefore, twenty-five steers per paddock were randomly selected on day 0 for body condition (BCS) scoring using a five-point scoring system (1-5) [30] and faecal samples taken in parallel with the weighing session. Blood samples were collected from these same 50 steers during days 0 and 147 weighing sessions.

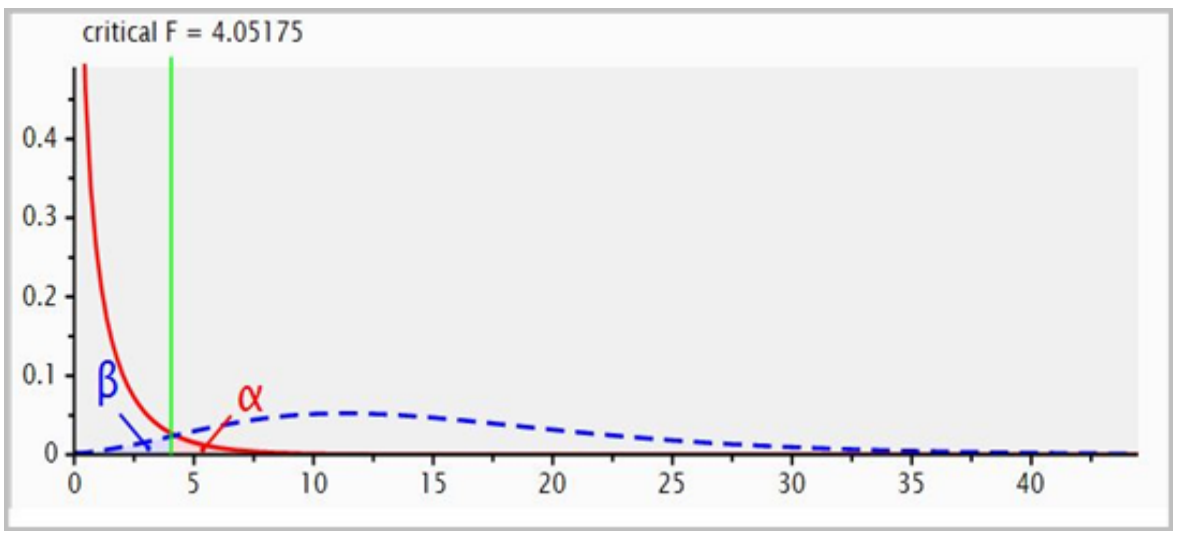

Figure 1. G-Power analysis for statistical power, critical F-value and sample size.

\subsection{Pasture Sampling and Analysis}

The Botanal technique [47] was used, pre- and post-grazing, to estimate pasture yield, botanical composition, ground cover and woody cover $[47,48]$. Since no substantial pasture growth was expected due to limiting moisture levels throughout the grazing period, grazing utilization was estimated as a percentage of the grazed stock as described by Stoddart [49]. Estimates were made in $0.50 \times 0.50 \mathrm{~m}$ quadrats assigned on a $100 \mathrm{~m} \times 100 \mathrm{~m}$ grid pattern on predetermined GPS points to ensure uniform sampling across the paddocks. The number of quadrats per paddock varied, with paddock size resulting to 595 and 507 quadrats for the buffel-grass-only and mixed buffel grass-Desmanthus paddocks, respectively. Representative pasture samples were collected from both paddocks, four times over the course of the experiment; at the beginning, end and twice during grazing. Buffel grass and Desmanthus were analysed as they were the dominant pastures, while Acacia harpophylla (brigalow) was the dominant woody cover, and steers were observed to browse on its leaves. Although they are palatable, S. kali, U. mosambiencensis and Portulaca spp. were not analysed because their contribution was minimal, below $5 \%$ of the pasture botanical composition. Buffel grass and Desmanthus samples were harvested by cutting at $5 \mathrm{~cm}$ above the ground while brigalow samples consisted of leaves and soft branches approximately $10 \mathrm{~cm}$ long. Pasture samples were transported in cooler boxes and stored at $-20^{\circ} \mathrm{C}$ until 
being analysed in the laboratory. The samples were oven dried at $60{ }^{\circ} \mathrm{C}$ for $48 \mathrm{~h}$, ground to pass through a $1 \mathrm{~mm}$ screen using a Cyclotec mill (Foss Tecator AB, Hoganas, Sweden) and analysed for neutral detergent fibre (NDF), acid detergent fibre (ADF), organic matter (OM), crude protein $(\mathrm{CP})$ and dry matter digestibility (DMD). Total nitrogen $(\mathrm{N})$ was determined by the Dumas combustion method using a Leco CN628 N Analyser (Leco, St. Joseph, MI, USA) [50] and CP calculated using total $\mathrm{N} \times 6.25$. NDF (without heat-stable $\alpha$ amylase) and ADF concentrations were determined sequentially using an ANKOM 200/220 Fibre Analyser (ANKOM Technology, Fairport, NY, USA) according to the methods of Van Soest et al. [51] and Goering and Van Soest [52], respectively, and hemicellulose was calculated as the difference between NDF and ADF. OM was determined by ashing the samples according to the methods of Faichney and White [53]. In vitro DMD was determined using a modified pepsin-cellulase technique [54] and metabolisable energy (ME) was calculated as DMD $\times 0.172-1.707$ [55].

\subsection{Faecal Sampling and Analysis}

To determine the nutritive value of the diet selected by the steers during grazing, faecal samples were collected from the rectum of 50 steers ( 25 from each paddock) and from random dung pats in each paddock close to the watering points on weigh days. Faecal samples were transported in a cooler box and stored at $-20^{\circ} \mathrm{C}$ awaiting laboratory analysis. The samples were dried and ground as previously described for the pasture samples. Faecal near infrared reflectance spectroscopy (FNIRS) (NIRSystems FOSS 6500) as described by Dixon and Coates [56,57] was used to determine CP, DMD, non-grass pasture proportion in the diet (comprising native and sown legumes, forbs and browse) and faecal $\mathrm{N}$ at the CSIRO Floreat laboratory (Floreat, WA, Australia). Spectral analyses, data manipulation and spectra calibrations were carried out using ISI (Infrasoft International) software NIRS 3 (Version 3.10, Port Matilda, PA, USA). The calibration equations used were developed for cattle grazing tropical and subtropical pastures [58,59].

\subsection{Plasma Metabolites Analysis}

To assess the steers' nutritional and health status, blood samples were collected at the start and end of the grazing period from the sample 50 steers by caudal venipuncture into $10 \mathrm{~mL}$ heparin-containing BD Vacutainer tubes. Plasma was isolated using a portable horizontal bench-top centrifuge (StatSpin Express 4, Iris Sample Processing, Westwood, MA, USA) at $4000 \times g$ for $5 \mathrm{~min}$ at room temperature. Plasma samples were transferred into labelled $15 \mathrm{~mL}$ aliquot tubes and stored at $-20{ }^{\circ} \mathrm{C}$ pending laboratory analysis. Plasma non-esterified fatty acids (NEFA), beta-hydroxybutyrate (BHB), total bilirubin, creatinine and glucose were analysed using the colorimetric, 3-hydroxybutyrate dehydrogenase, modified diazo, kinetic modified Jaffe and hexokinase methods of the AU480 chemistry analyser (Beckman Coulter, Inc., Brea, CA, USA), respectively, according to the manufacturer's procedures.

\subsection{Statistical Analysis}

All data were analysed using SAS software version 9.4 (SAS Institute, Cary, NC, USA). Growth performance and blood metabolites data were analysed using the General Linear Model procedure (PROC GLM) analysis of variance with the animal as the experimental unit. Backgrounding pasture, days since onset of grazing and their interactions were fitted as fixed effects, while liveweight (LW), NEFA, BHB, total bilirubin, creatinine and glucose were the dependent variables. The same model was used for the faecal parameters analysis with backgrounding pasture, month and their interactions fitted as fixed effects and faecal N, diet CP, DMD and diet non-grass as the dependent variables. Backgrounding pasture was the only fixed effect for the ADG analysis. Effects were declared significant at $p \leq 0.05$. Where significant, differences between means were tested by least significant difference (LSD) comparison test. Simple linear regression using the PROC REG was used to determine the relationship between diet non-grass and CP or CP and DMD. 


\section{Results}

\subsection{Rainfall and Pasture Characteristics}

Throughout the pasture establishment and grazing periods, the total annual rainfall was below average (598.2 mm/annum) at 421, 368 and $305 \mathrm{~mm}$ for the years 2017, 2018 and 2019, respectively (Table 1). The wet season preceding the grazing period commenced in October 2018 and ended in April 2019. The rest of the year was fairly dry, and the next wet season had not started by the time grazing period ended in December 2019.

Table 1. Monthly and total annual rainfall (mm) for the years 2017, 2018 and 2019.

\begin{tabular}{cccccccccccccc}
\hline Year & Jan & Feb & Mar & Apr & May & Jun & Jul & Aug & Sep & Oct & Nov & Dec & Annual Total \\
\hline 2017 & 68 & 39 & 105 & 6 & 8 & 0 & 22 & 0 & 0 & 107 & 42 & 24 & 421 \\
2018 & 19 & 118 & 36 & 6 & 0 & 24 & 4 & 10 & 4 & 68 & 41 & 38 & 368 \\
2019 & 0 & 1 & 111 & 82 & 3 & 5 & 24 & 15 & 0 & 40 & 20 & 5 & 306 \\
\hline
\end{tabular}

Table 2 presents DM yield, ground cover, woody cover and the five most dominant pastures species in the two paddocks. Native legumes and forbs such as Rhynchosia minima, Sida spp., Convolvulus spp., Cleome viscosa and Abutilon andrewsianum were below $0.2 \%$. Buffel grass utilisation in the buffel grass and Desmanthus paddocks was $36.5 \%$ and $48.7 \%$, respectively, while Desmanthus utilisation was $83.5 \%$. Proximate analysis data of the pastures are presented in Table 3. CP was lowest in buffel grass and highest in Desmanthus, while DMD and ME were higher in brigalow compared to buffel grass and Desmanthus.

Table 2. Pasture characteristics of the buffel grass and Desmanthus paddocks prior to commencing and at the end of the grazing period. Data presented in percentages unless otherwise stated.

\begin{tabular}{ccccc}
\hline \multirow{2}{*}{ Variable } & \multicolumn{2}{c}{ Buffel Grass Paddock } & \multicolumn{2}{c}{ Desmanthus Paddock } \\
\cline { 2 - 5 } & Pre-Grazing & End of Grazing & Pre-Grazing & End of Grazing \\
\hline Ground cover & 63.7 & 38.0 & 68.7 & 29.7 \\
Woody Cover & 0.7 & 0.7 & 0.5 & 0.7 \\
Dry matter yield (kg/ha) & & & & \\
Total yield & 4066 & 1854 & 4509 & 1425 \\
Cenchrus ciliaris & 3532 & 1700 & 3372 & 1260 \\
Desmanthus spp. & & & 502 & 88.6 \\
$\quad$ Salsola kali & 8.0 & 4.2 & 131 & 3.9 \\
Urochloa mosambicensis & 158 & 57.2 & 112 & 28.1 \\
Portulaca spp. & 18.0 & 5.5 & 80.0 & 2.1 \\
Botanical composition & & & & \\
Cenchrus ciliaris & 90.1 & 91.7 & 77.2 & 88.4 \\
Desmanthus spp. & & & 11.5 & 6.2 \\
Salsola kali & 0.2 & 0.3 & 3.0 & 0.3 \\
Urochloa mosambicensis & 4.0 & 3.1 & 2.6 & 2.0 \\
Portulaca spp. & 0.5 & 0.3 & 1.8 & 0.2 \\
\hline
\end{tabular}

Table 3. Mean chemical composition and dry matter digestibility ( \pm standard deviation) of buffel grass, Desmanthus and brigalow leaves during the backgrounding period. Data are in \%DM unless otherwise stated.

\begin{tabular}{cccc}
\hline Variable & Buffel Grass & Desmanthus & Brigalow \\
\hline DM (\%) & $84.9 \pm 3.1$ & $68.3 \pm 3.4$ & $64.6 \pm 1.6$ \\
Neutral detergent fibre & $73.9 \pm 1.0$ & $62.8 \pm 2.0$ & $38.7 \pm 0.5$ \\
Acid detergent fibre & $43.4 \pm 1.1$ & $40.9 \pm 1.6$ & $25.5 \pm 1.5$ \\
Dry matter digestibility & $46.9 \pm 1.1$ & $48.4 \pm 1.2$ & $60.6 \pm 1.1$ \\
Organic matter & $93.1 \pm 0.3$ & $94.6 \pm 0.5$ & $91.8 \pm 0.3$ \\
Ash & $7.2 \pm 0.2$ & $5.4 \pm 0.5$ & $8.2 \pm 0.3$ \\
Hemicellulose & $30.5 \pm 1.3$ & $21.9 \pm 2.0$ & $13.2 \pm 2.0$ \\
Crude Protein $\left.^{-1} \mathrm{DM}\right)^{1}$ & $4.4 \pm 0.9$ & $8.5 \pm 1.4$ & $7.5 \pm 0.3$ \\
Metabolizable energy (Mj· $\mathrm{kg}^{-1}{ }^{-1}$ & $6.9 \pm 0.1$ & $6.8 \pm 0.128$ & $8.7 \pm 0.2$ \\
\hline
\end{tabular}

$\mathrm{DM}=$ dry matter ${ }^{1}$ Estimated from in vitro DMD as DM digestibility $\times 0.172-1.707$ [55]; MJ = megajoules. 


\subsection{Diet Selected during Grazing}

Diet $\mathrm{CP}$ and DMD were similar throughout the study for the steers on buffel grass, but varied significantly for the steers on Desmanthus, with the lowest values recorded on day 49 (Table 4). Faecal $\mathrm{N}$ did not vary with backgrounding pasture but reduced significantly by the end of grazing $(p=0.001)$. There was no effect of pasture on the non-grass diet, but a decrease over time ( $p=0.001)$ was observed, with the lowest values recorded on day 147 . At the beginning of the study, there was no difference in the quality of diet selected by the two groups. The initial diet similarity is indicated by the similar CP, Faecal N, DMD and diet non-grass on day 0. Overall, DMD was higher for the buffel grass than the Desmanthus steers $(55.5 \%$ and $54.2 \%$, respectively; $p=0.001)$.

Table 4. Effect of pasture backgrounding on dietary $\mathrm{CP}, \mathrm{DMD}$, diet non-grass and faecal $\mathrm{N}$ as estimated from faecal near infrared reflectance spectroscopy.

\begin{tabular}{|c|c|c|c|c|c|c|c|c|c|}
\hline \multirow{2}{*}{ Variable } & \multirow{2}{*}{ Paddock } & \multicolumn{4}{|c|}{ Days Since the Onset of Grazing } & \multirow{2}{*}{ SEM } & \multicolumn{3}{|c|}{$p$-Value } \\
\hline & & 0 & 49 & 79 & 147 & & $\mathbf{P}$ & $\mathbf{D}$ & $\mathbf{P}^{*} \mathbf{D}$ \\
\hline \multirow{2}{*}{ Diet CP (\%) } & Buffel grass & $11.26^{\mathrm{ab}}$ & $11.70^{a}$ & $10.99 \mathrm{ab}$ & $10.92^{\mathrm{ab}}$ & \multirow{2}{*}{0.995} & \multirow{2}{*}{0.001} & \multirow{2}{*}{0.001} & \multirow{2}{*}{0.001} \\
\hline & Desmanthus & $11.28^{a b}$ & $8.78^{\mathrm{d}}$ & $10.61^{b c}$ & $9.94^{c}$ & & & & \\
\hline \multirow{2}{*}{ Faecal N (\%) } & Buffel grass & $1.75^{\mathrm{a}}$ & $1.75^{\mathrm{a}}$ & $1.73^{\mathrm{a}}$ & $1.56^{\mathrm{b}}$ & \multirow{2}{*}{0.150} & \multirow{2}{*}{0.68} & \multirow{2}{*}{0.001} & \multirow{2}{*}{0.14} \\
\hline & Desmanthus & $1.74^{\mathrm{a}}$ & $1.73^{\mathrm{a}}$ & $1.79^{\mathrm{a}}$ & $1.49^{b}$ & & & & \\
\hline \multirow{2}{*}{$\operatorname{DMD}(\%)$} & Buffel grass & $53.94^{c}$ & $55.11 \mathrm{ab}$ & $55.07^{a b}$ & $55.92^{a}$ & \multirow{2}{*}{1.24} & \multirow{2}{*}{0.001} & \multirow{2}{*}{0.001} & \multirow{2}{*}{0.001} \\
\hline & Desmanthus & $54.16^{\mathrm{bc}}$ & $52.09^{\mathrm{d}}$ & $54.72^{b c}$ & $53.83^{c}$ & & & & \\
\hline \multirow{2}{*}{$\begin{array}{c}\mathrm{ME} \\
(\mathrm{MJ} / \mathrm{Kg} \mathrm{DM})^{1}\end{array}$} & Buffel grass & $7.57^{c}$ & $7.77^{a b}$ & $7.76^{a b}$ & $7.91^{\mathrm{a}}$ & \multirow{2}{*}{0.0381} & \multirow{2}{*}{0.001} & \multirow{2}{*}{0.001} & \multirow{2}{*}{0.001} \\
\hline & Desmanthus & $7.61^{b c}$ & $7.25^{d}$ & $7.71^{b c}$ & $7.55^{b c}$ & & & & \\
\hline \multirow{2}{*}{ DNG (\%) } & Buffel grass & $32.40^{\mathrm{a}}$ & $28.09 \mathrm{bc}$ & $26.27^{c}$ & $19.94^{\mathrm{d}}$ & \multirow{2}{*}{4.91} & \multirow{2}{*}{0.65} & \multirow{2}{*}{0.001} & \multirow{2}{*}{0.089} \\
\hline & Desmanthus & $31.87^{a b}$ & $27.72^{c}$ & $28.52^{a b c}$ & $17.37^{d}$ & & & & \\
\hline
\end{tabular}

abcd Means followed by different letters in the same row are significantly different between pastures and days at the $p<0.05 .{ }^{1}$ Estimated from in vitro $\mathrm{DMD}$ as $\mathrm{DM}$ digestibility $\times 0.172-1.707$ [55]; $\mathrm{MJ}=$ megajoules; $\mathrm{SEM}=$ standard error of the mean; $\mathrm{P}=$ paddock; $\mathrm{D}=$ sampling day; $P^{*} \mathrm{D}=$ paddock and days interaction; $\mathrm{CP}=$ crude protein, $\mathrm{N}=$ nitrogen; $\mathrm{DMD}=$ dry matter digestibility; $\mathrm{DNG}=$ diet non-grass.

A positive relationship was observed between the diet $\mathrm{CP}$ and non-grass (Figure 2; $p<0.001)$. CP increased with an increase in diet non-grass component, while DMD increased with an increase in diet CP (Figure $3 ; p<0.001$ ). However, diet non-grass accounted for only $16 \%$ variability in $\mathrm{CP}$, while $\operatorname{diet} \mathrm{CP}$ accounted for $34 \%$ variability in $\mathrm{DMD}$ (Figure 3).

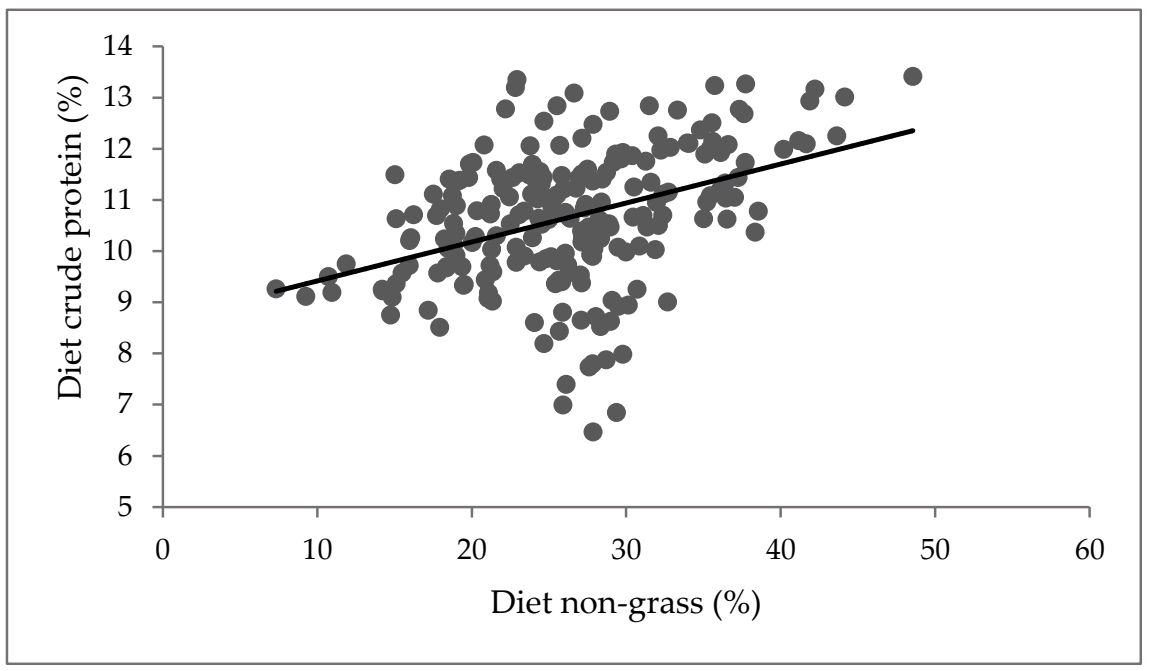

Figure 2. Relationship between diet non-grass and crude protein. $\mathrm{Y}=8.66+0.076 \mathrm{X}$; where $\mathrm{Y}=$ diet crude protein and $\mathrm{X}=$ diet non-grass, $\mathrm{R}^{2}=0.16, p<0.001$. 


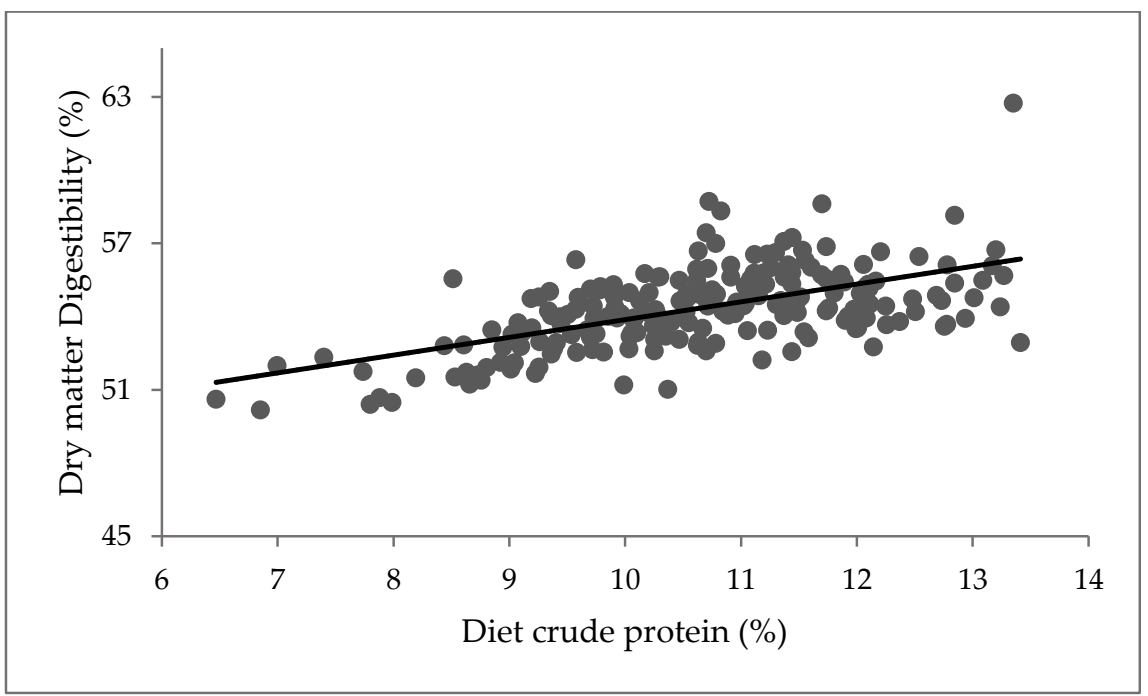

Figure 3. Relationship between diet crude protein and dry matter digestibility $\mathrm{Y}=46.60+0.728 \mathrm{X}$; where $\mathrm{Y}=\% \mathrm{DMD}$ and $\mathrm{X}=\% \mathrm{CP}, \mathrm{R}^{2}=0.34, p<0.001$.

\subsection{Plasma Metabolites}

Plasma metabolite data are presented in Table 5. No significant difference in plasma metabolites concentration was observed for steers backgrounded on Desmanthus-buffel grass mixed compared to buffel-grass-only pastures, although NEFA tended to be higher for the buffel-grass steers $(p=0.058)$, whereas sampling period had a significant effect on all metabolites except NEFA. Total bilirubin $(p=0.041)$ and glucose $(p=0.001)$ decreased, while BHB $(p=0.001)$ and creatinine $(p=0.001)$ increased for both groups, although the BHB increase in the Desmanthus group was not significant. An interaction between period and pasture $(p=0.011)$ was observed for the creatinine with a greater increase observed for the Desmanthus than the buffel-grass steers.

Table 5. Effect of pasture backgrounding on plasma metabolites (LS means).

\begin{tabular}{|c|c|c|c|c|c|c|c|}
\hline \multirow{2}{*}{ Metabolite } & \multirow{2}{*}{ Pasture } & \multicolumn{2}{|c|}{ Sampling Period } & \multirow{2}{*}{ SEM } & \multicolumn{3}{|c|}{$p$-Value } \\
\hline & & Day 0 & Day 147 & & $\mathbf{P}$ & D & $P^{*} \mathrm{D}$ \\
\hline \multirow{2}{*}{$\begin{array}{l}\text { Total Bilirubin } \\
\quad(\mu \mathrm{mol} / \mathrm{L})\end{array}$} & Buffel grass & 2.93 & 2.29 & \multirow{2}{*}{1.21} & \multirow{2}{*}{0.41} & \multirow[b]{2}{*}{0.041} & \multirow[b]{2}{*}{0.094} \\
\hline & Desmanthus & 2.81 & 2.30 & & & & \\
\hline \multirow{2}{*}{$\mathrm{BHB}(\mathrm{mmol} / \mathrm{L})$} & Buffel grass & 0.22 & 0.28 & \multirow[b]{2}{*}{0.0603} & \multirow[b]{2}{*}{0.35} & \multirow[b]{2}{*}{0.001} & \multirow{2}{*}{0.68} \\
\hline & Desmanthus & 0.21 & 0.25 & & & & \\
\hline \multirow{2}{*}{$\begin{array}{c}\text { Creatinine } \\
(\mu \mathrm{mol} / \mathrm{L})\end{array}$} & Buffel grass & 94.48 & 109.15 & \multirow{2}{*}{16.27} & \multirow{2}{*}{0.12} & \multirow{2}{*}{0.001} & \multirow{2}{*}{0.011} \\
\hline & Desmanthus & 89.25 & 122.70 & & & & \\
\hline \multirow{2}{*}{$\begin{array}{c}\text { NEFA } \\
(\mathrm{mmol} / \mathrm{L})\end{array}$} & Buffel grass & 0.45 & 0.36 & \multirow{2}{*}{0.177} & \multirow{2}{*}{0.058} & \multirow{2}{*}{0.21} & \multirow{2}{*}{0.31} \\
\hline & Desmanthus & 0.36 & 0.33 & & & & \\
\hline \multirow{2}{*}{$\begin{array}{c}\text { Glucose } \\
(\mathrm{mmol} / \mathrm{L})\end{array}$} & Buffel grass & 5.9 & 4.8 & \multirow{2}{*}{1.00} & \multirow{2}{*}{0.46} & \multirow{2}{*}{0.001} & \multirow{2}{*}{0.40} \\
\hline & Desmanthus & 5.7 & 4.8 & & & & \\
\hline
\end{tabular}

$\overline{\mathrm{BHB}}=\beta$-hydroxybutyrate; NEFA $=$ non-esterified fatty acids; SEM = standard error of the mean; $\mathrm{P}=$ pasture $\mathrm{D}=$ sampling day; $\mathrm{P}^{*} \mathrm{D}=$ pasture and sampling day interaction.

\subsection{Growth Performance}

Steer LW, BCS and ADG data are presented in Table 6. Backgrounding pastures did not affect steers' performance. An increase in LW and BCS was observed throughout the study $(p<0.001)$. Steers' final LW was 431 and $433 \mathrm{~kg}$, and BCS was 4.1 and 3.9 for the buffel grass and Desmanthus paddock steers, respectively. 
Table 6. LW, ADG and BCS of steers backgrounded on buffel grass alone or with Desmanthus.

\begin{tabular}{|c|c|c|c|c|c|c|c|c|c|}
\hline \multirow{2}{*}{ Variable } & \multirow{2}{*}{ Pasture } & \multicolumn{4}{|c|}{ Days Since the Onset of Grazing } & \multirow{2}{*}{ SEM } & \multicolumn{3}{|c|}{$p$-Value } \\
\hline & & 0 & 49 & 79 & 147 & & $\mathbf{P}$ & Days & $P * D$ \\
\hline \multirow{2}{*}{ LW (kg) } & Buffel grass & $319^{\mathrm{d}}$ & $372^{c}$ & $392^{b}$ & $431^{\mathrm{a}}$ & \multirow[b]{2}{*}{18.9} & \multirow[b]{2}{*}{0.14} & \multirow[b]{2}{*}{0.001} & \multirow[b]{2}{*}{0.21} \\
\hline & Desmanthus & $322^{d}$ & $369^{c}$ & $396^{\mathrm{b}}$ & $433^{a}$ & & & & \\
\hline \multirow{2}{*}{ BCS } & Buffel grass & $3.46^{c}$ & $3.60^{b c}$ & $3.58^{b c}$ & $4.10^{\mathrm{a}}$ & \multirow{2}{*}{0.38} & \multirow{2}{*}{0.51} & \multirow{2}{*}{0.001} & \multirow{2}{*}{0.36} \\
\hline & Desmanthus & $3.46^{c}$ & $3.65^{b c}$ & $3.59 \mathrm{bc}$ & $3.90^{a b}$ & & & & \\
\hline \multirow{2}{*}{$\begin{array}{c}\text { Overall ADG } \\
(\mathrm{kg} / \text { day })\end{array}$} & Buffel grass & \multirow{2}{*}{\multicolumn{4}{|c|}{$\begin{array}{l}0.74 \\
0.75\end{array}$}} & \multirow{2}{*}{0.13} & \multirow{2}{*}{0.78} & & \\
\hline & Desmanthus & & & & & & & & \\
\hline
\end{tabular}

\section{Discussion}

\subsection{Pasture Characteristics}

The DM yield of the buffel grass pasture in this study (3.4-3.6 ton/ha) was lower than that average reported for the buffel grass pastures in the Brigalow region of Central Queensland (4.5-5.2 ton/ha) [60]. The low yield could be due to the below-average rainfall received during the study period [61]. Although Desmanthus contributed a small proportion of initial pasture biomass (11.5\%) in the study, pasture DM yield was $443 \mathrm{~kg} / \mathrm{ha}$ higher in the Desmanthus paddock compared to the buffel-grass-only paddock. This finding agrees with other studies that reported an increase in pasture yield when legumes were oversown with grass pastures compared to grass-only pastures in the tropics $[62,63]$. The presence of $11-33 \%$ legumes in temperate pastures was found to increase DM yield, but with a reduced yield benefit as the legume proportion increased to $67 \%$ or more [64]. Legumes increase pasture productivity by contributing to increased light capture compared to pure grass stands [65]. Furthermore, nitrogen-fixing legumes promote grass growth by providing nitrogen for the companion grass if moisture is not limiting [66,67].

The CP of Desmanthus in this study was lower than that reported for D. leptophyllus, D. virgatus and $D$. bicornutus grown in a semi-enclosed greenhouse in winter $(11.2-18.9 \%)$ and spring (13.2-18.2\%) seasons [22]. Durmic et al. [68] reported 12.2 to $21 \% \mathrm{CP}$ in winter and $9.8-19.2 \% \mathrm{CP}$ in spring. However, one cultivar-D. virgatus (Marc) had a CP content of $6.2 \%$ in spring. In this study, buffel grass $\mathrm{CP}$ was very low (4.4\%). The low $\mathrm{CP}$ agrees with a review of studies carried out in Central Queensland that reported a decline in buffel grass $\mathrm{CP}$ to below $6 \%$ in winter [6].

\subsection{Diet Selected during Grazing}

Dietary CP and DMD are the primary limiting factors of growth performance in cattle grazing low-quality pastures in the Australian subtropics during the dry season [69]. Limited CP levels result in below-optimal microbial growth required for structural carbohydrate digestion in the rumen, which in turn depresses feed intake [69,70]. In this study, steers in both paddocks consumed diets with higher CP (8.8-11.6\%), DMD (52.1-55.9\%) and ME (7.3-7.9 MJ/Kg DM) compared to the CP (4.4-8.5\%), DMD (46.9-48.4) and ME (6.8-6.9 MJ/Kg DM) obtained from the pasture proximate analysis. Although, the brigalow DMD and ME were higher at $60.6 \%$ and $8.7 \mathrm{MJ} / \mathrm{Kg} \mathrm{DM}$, respectively. Ruminants consume diets that differ from the average available biomass in plant species, plant parts and nutrient content $[71,72]$ as a result of foraging behaviour influenced by short-term and long-term decisions, such as which plant to select, how long to search between bites and where to graze [72]. Hence, pasture samples do not adequately represent the diet consumed by grazing animals [73].

It was surprising to observe similar diet non-grass components in the consumed diet of steers in both paddocks. Steers on buffel grass might have consumed non-grass pastures from forbs, native legumes and woody shrubs. Bowen et al. reported $11 \%$ C 3 
forage biomass in cattle grazing C4 perennial-grasses-only pastures and attributed it to naturalised legumes and other dicots present in the pastures [74]. The CP and DMD of selected pastures were lower than those selected by steers grazing the Leucaena-grass pasture (12.4\% and $62 \%$, respectively) [57]. However, CP was higher and DMD was similar to that reported for cattle grazing varying perennial grass pastures, forbs and shrubs that consumed a diet with 5.5-8.11\% CP and 52.1-55.2\% DMD [75]. Although metabolisable protein is a better measure of protein requirement than CP [55], it was not possible to determine the metabolisable protein of the diet selected by steers in this study. Dixon and Coates [76] reported that rumen degradable $\mathrm{N}$ is likely to be restrictive only when the DMD: $\mathrm{CP}$ ratio exceeds 8 to 10. In the current study, the DMD: $\mathrm{CP}$ ratio ranged between 4.8 and 5.9 for both paddocks, indicating that rumen degradable $\mathrm{N}$ was not limiting [76].

Non-grass pastures constituted between $17.4-32.4 \%$ of the diet consumed. This falls within the range reported for heifers grazing a mixture of Verano and Seca stylos with Sabi grass that selected 15-63\% stylo [14]. Among the factors that influence the diet composition of grazing animals are pasture species on offer, availability, palatability and nutritive value of the associated grass [56]. Leucaena in the diet was observed to decline steeply from $87 \%$ to $10 \%$ with reducing availability during the dry season [57]. In another study, where the entire cattle diet consisted of Mulga (Acacia aneura) during the dry season when Mulga was the only available forage, the Mulga proportion reduced to 30\% during the wet season when moisture stimulated grass growth [56]. In grass-dominated pastures, cattle consumed $10 \%$ non-grass components during the pasture growing season, which increased to over $70 \%$ in the dry season [56]. Cattle grazing varying perennial grass pastures, forbs and shrubs consumed 19-49\% non-grass components [75]. In the Mitchell-grass-dominated pastures, the non-grass proportion in sheep and cattle diets was high during the wet season and reduced in the dry season. The authors attributed the trend to high palatability of the non-grass pasture species encouraging higher preference when available, but consumption dropped with a decrease in availability during the dry season [56,77]. In grass-dominated pastures consisting of just $2 \%$ forbs, cattle consumed up to $15 \%$ non-grass during the dry season, indicating high forb selection [56]. Forb and browse are often higher in $\mathrm{N}$ and metabolisable energy than grasses, especially when grasses are senesced [78,79]. These studies indicate that cattle can consume large amounts of palatable non-grass pastures when not limited by availability. Desmanthus utilisation in the current study was very high $(83.5 \%)$ suggesting that consumption was limited by availability. Therefore, a higher percentage of Desmanthus legume in the pastures may be required for improved non-grass pastures and CP intake to be observed. Thomas [67] suggested that 20-30\% DM legume content is required for $10-40 \%$ pasture utilisation, and $35-45 \%$ DM legume at higher pasture utilisation levels of $50-70 \%$ for a productive and sustainable pasture.

\subsection{Plasma Metabolites}

More accurate assessment of nutritional and health status in cattle can be achieved by including plasma metabolites analysis than from BCS and LW alone [30]. The glucose levels were similar to those reported for cattle grazing dormant pastures $[80,81]$ and were within the normal range for beef cattle $(2.5$ to $5.5 \mathrm{mmol} / \mathrm{L})[82,83]$. The lack of difference in glucose concurred with results for cattle fed low-quality Sudan grass (Sorghum sp.) hay (CP 3.9\%) supplemented with soybean alone or with pelleted Silver-grass (Miscanthus sp.) to achieve $9.6 \% \mathrm{CP}$ levels [84]. The decline in glucose from the start to the end of the grazing period is in agreement with results reported in other studies. For instance, rangeland-grazing beef cattle blood glucose decreased from summer, fall, winter to spring [36]. Similarly, a decline in blood glucose was reported for temperate-breed steers during the 'store' period [85]. The glucose decline over time can be explained by a decline in feed intake resulting from declining pasture availability $[30,36]$.

Backgrounding pastures did not influence plasma NEFA concentration, indicating that steers were not mobilising body energy reserves in the current study [36,37]. NEFA levels are reported to increase with maturity of forage, which could indicate a negative energy 
balance [36,37]. In this study, grazing started when the pastures had senesced; hence, no difference in maturity over time was taking place. The increase in BHB levels over time for the buffel-grass steers was unexpected since there was no difference in the NEFA levels. However, this increase was marginal and the plasma BHB level was below a $1.2 \mathrm{mmol} / \mathrm{L}$ concentration reported as the threshold to indicate hyperketonemia in cows [86].

Creatinine is produced mainly in the skeletal muscles by the degradation of creatine and creatine phosphate to produce energy [87] and it is commonly associated with renal disorders [88]. Reduced creatinine levels are also indicative of prolonged tissue protein catabolism [30]. In this study, all the steers had creatinine levels within the normal range reported for cows (88.4-177 $\mu \mathrm{mol} / \mathrm{L})$ [87] and bulls (98.7 $\pm 14.7 \mu \mathrm{mol} / \mathrm{L})$ [89]. Creatinine levels increased with time for both groups indicating that no catabolism was taking place but rather an increase in muscle mass [30,90].

Bilirubin levels were similar to the normal range reported for extensive range beef cattle $[88,89]$ and the Angoni cattle on grass pastures $(2.7 \pm 1.4 \mu \mathrm{mol} / \mathrm{L})$, although the quality of the pasture was not described [89]. Issi et al. [91] reported elevated total bilirubin levels in dairy cows diagnosed with subclinical and clinical ketosis. The authors associated the bilirubin increase with the existence of a functional disorder or liver damage. The similar levels of total bilirubin in the current study may indicate that the caloric intake of steers on both pastures was comparable. It is pertinent to state that going by the plasma metabolite profiles, all the steers in this study were healthy; indicating that, with or without Desmanthus inclusion in the diet of grazing steers, animal health status was not compromised.

\subsection{Growth Performance}

The animal growth response to grass pastures oversown with legumes depends on legume yield and quality [46]. Contrary to other studies that reported an increase in LW gain in cattle [26,43], sheep [28,92] and goats [93] supplemented with Desmanthus compared to their counterparts fed grass only diets, no difference was observed in this study. This could be due to the lack of increase in diet CP intake in the Desmanthus paddock compared to the buffel grass paddock due to low Desmanthus levels. An increase in weight gain for cattle supplemented with other tropical legumes has been reported [74,94-96]. Zebu steers grazing low-quality standing hay supplemented with $0.8 \mathrm{~kg}$ DM Leucaena leaf meal improved daily weight gain from -0.3 to $0.26 \mathrm{~kg}$ [97]. Miranda et al. [98] reported a $0.7 \mathrm{~kg}$ higher daily weight gain for cattle supplemented with Stylosanthes guianensis compared to cattle fed rice straw and Brachiaria spp. grass only. Similar to our study, Suybeng et al. [23] reported no difference in LW gain between steers fed Rhodes grass only or supplemented with different levels of Desmanthus. The authors attributed the results to low diet ME (6.1-8.2 MJ/Kg DM) and feed intake (1.2-1.6\% per Kg LW) that resulted in low daily ME intake (22-39 MJ/Kg DM). In the current study, the selected diet contained at least 7.3 MJ/Kg DM ME, but feed intake could not be determined. Steers in both paddocks had similar weight gain and BCS, and no weight loss was recorded. The finding concurs with a review of eleven studies by Bowman et al. [99] who reported that a pasture diet with $\mathrm{CP}$ above $5.6 \%$ results in weight gain. Detmann et al. [100] estimated that $10.8 \mathrm{~g} / \mathrm{kg} \mathrm{CP}$ is required to achieve the apparent equilibrium point where the $\mathrm{N}$ efficiency of utilisation is nil. A 5.6\% CP level was achieved in both paddocks throughout the study while $10.8 \mathrm{~g} / \mathrm{kg}$ CP failed to be achieved only on days 49 and 147 in the Desmanthus paddock. This may indicate that dietary $C P$ in this study was sufficient for rumen microbial growth $[9,69,101]$. Regardless of the lower dietary CP on days 49 and 147 for the Desmanthus steers, no effect on $\mathrm{LW}$ was observed. This could be due to the $\mathrm{CP}$ and DMD: $\mathrm{CP}$ ratio that persisted above 5.6 and 8 , respectively $[76,99]$, maintaining sufficient rumen function. Supplementing steers with $15 \%, 22 \%$ and $31 \%$ Desmanthus was observed to improve rumen function as indicated by the increased total volatile fatty acids concentration in the rumen [23]. Therefore, more studies are required to understand the effect of Desmanthus on rumen function. 
The ADG of steers grazing buffel-grass-only pastures $(0.74 \mathrm{~kg} /$ day) was within the 0.2 to $>1.0 \mathrm{~kg}$ range reported for buffel grass pastures in the Brigalow region of Queensland [6] However, this is higher than the 0.11 and $0.44 \mathrm{~kg} /$ day reported for buffel grass only and buffel grass-Desmanthus pastures, respectively, in a similar environment [26], and -0.25 to $0.17 \mathrm{~kg} /$ day reported for steers grazing buffel-grass-dominated pastures in the monsoonal climate region of Northern Territory during the dry season [102]. The variance in ADG could be due to differences in stocking rate resulting in varying pasture availability. The stocking rate was $0.55-1.92 \mathrm{ha} /$ steer compared to 2.57 and $3.02 \mathrm{ha} /$ steer in the present study. Individual animal weight gain declines with an increase in stocking rate when not accompanied by increase in pasture biomass due to competition for forage [4].

The main drivers of profitability in grazing systems are annual liveweight gain and the stocking rate [6]. Although the final liveweight for both groups was similar in the current study, the buffel grass-Desmanthus mixed paddock had a higher stocking rate compared to the buffel-grass-only paddock by $9.5 \%$. Increasing the stocking rate increases the annual LW per ha [103], promoting profitability [6]. In our study, liveweight gain per hectare was calculated to be 37.8 and $42.4 \mathrm{~kg} / \mathrm{ha}$ for the buffel and Desmanthus pastures, respectively. A strong correlation between the cattle stocking rate and the daily live weight gain $\left(R^{2} \leq 0.93\right)$ was reported for beef cattle grazing grass-dominated pastures with $5-8.1 \%$ $\mathrm{CP}$ [104]. The authors associated the decline in LW as the stocking rate increased with reduced pasture availability.

Legumes offer the greatest weight gain advantage during the late wet and the dry seasons [14]. This study took place during the dry season only; hence, the response of the steers to Desmanthus pastures during the wet and transition seasons was not examined. Cattle grazing buffel grass and Centrosema brasilianum (Centro) were observed to select more Centro during the wet to dry transition season than during the dry season at $22.1-40 \%$ and $19.7-20.9 \%$, respectively [103]. A similar trend was reported for Chamaecrista rotundifolia [105]. However, low nutritive value and palatability of pasture in the seasonally dry subtropics of northern Australia are endemic in the dry season $[70,106]$, hence more controlled pen studies are required to determine the effect of varying levels of Desmanthus on the rumen fermentation and growth performance of grazing cattle during the dry season. In addition, previous grazing nutrition is reported to influence the growth performance of cattle during the feedlot finishing phase and carcass traits [107]. Further studies are required to determine the feedlot growth performance and carcass quality of Desmanthus backgrounded beef cattle.

\section{Conclusions}

This study evaluated the possibility of using Desmanthus legume oversown in Buffel grass pastures to improve growth performance and plasma metabolites profile during the nutrient-limiting dry season in Northern Australia. The results showed no significant effect of Desmanthus at low inclusion levels in backgrounding pastures on LW, weight gain and plasma metabolites. Therefore, the hypothesis that backgrounding steers on Buffel grass-Desmanthus mixed pastures would elicit significant changes in plasma glucose, bilirubin, creatinine, non-esterified fatty acids and $\beta$-hydroxybutyrate, resulting in higher liveweight gains than in steers on buffel grass only pastures was rejected. Though the lack of difference may be due to the high performance of the buffel grass pastures atypical for the dry season in this region, the main drivers of profitability in grazing systems are annual liveweight gain and stocking rate. The similar weight gain at higher stocking rate indicate that Desmanthus may have the potential to improve profitability in the extensive grazing systems of northern Australia and other similar environments by improving pasture carrying capacity. Further research is required to investigate the effect of feedlotting and on-station pen feeding trial with the Desmanthus legume to better understand its effect on growth, plasma metabolites, rumen volatile fatty acids, carcass characteristics and meat quality parameters of intramuscular fat content, fat melting point and muscle fatty acid composition in beef cattle. In addition, studies are required to evaluate the growth 
performance and plasma metabolites of cattle backgrounded on grass pastures oversown with higher levels of Desmanthus.

Author Contributions: Conceptualisation, A.E.O.M.-A., C.P.G., G.W., B.S.M.-A., R.T.K. and F.W.M.; methodology, A.E.O.M.-A., C.P.G., B.S.M.-A., R.T.K., G.W., T.J.H. and F.W.M.; software, A.E.O.M.-A.; validation, A.E.O.M.-A., C.P.G., R.T.K., G.W., T.J.H. and B.S.M.-A.; formal analysis, F.W.M.; investigation, F.W.M.; resources, A.E.O.M.-A., C.P.G., R.T.K. and B.S.M.-A.; data curation, writing-original draft preparation, F.W.M.; writing-reviewing and editing, A.E.O.M.-A., C.P.G., T.J.H., R.T.K. and B.S.M.-A.; supervision, A.E.O.M.-A., C.P.G., R.T.K. and B.S.M.-A.; project administration, A.E.O.M.-A., C.P.G.; funding acquisition, A.E.O.M.-A., C.P.G. and G.W. All authors have read and agreed to the published version of the manuscript.

Funding: This research was funded by the Cooperative Research Centre Projects (CRC-P) [grant number CRC P-58599] from the Australian Government's Department of Industry, Innovation and Science, and a PhD scholarship funded by CRC-P and the College of Public Health, Medical and Veterinary Sciences, James Cook University, Queensland, Australia, awarded to the first named author.

Institutional Review Board Statement: The study was conducted according to the guidelines of the Australian code of practice for the care and use of animals for scientific purposes (8th Edition, 2013), and approved by the James Cook University Animal Ethics Committee (Approval Number 2639, issued on the 5 July 2019).

Informed Consent Statement: Not applicable.

Data Availability Statement: Data available on request.

Acknowledgments: The authors thankfully acknowledge James Cook University's (JCU) College of Public Health, Medical and Veterinary Sciences, Townsville, QLD, the Cooperative Research Centre Projects (CRC-P), Canberra, ACT, Meat \& Livestock Australia Ltd. (MLA), Sydney, NSW, the Commonwealth Scientific and Industrial Research Organisation (CSIRO)-JCU-Agrimix Pastures Pty Ltd. Joint Research Project and the North Australian Pastoral Company (NAPCo), Queensland. We appreciate Darryl Savage for ensuring a smooth working relationship between NAPCo and the researchers. We are also grateful to the station staff led by Jason and Donna Collins for support with grazing management and cattle handling. Benedicte Suybeng, Stefania Maffei and Shedrach Pewan are appreciated for their help with sampling. We also acknowledge the technical support provided by Elizabeth Hulm for pasture and faecal analysis and Jemma Green for plasma metabolites analysis.

Conflicts of Interest: The authors declare no conflict of interest. The funders had no role in the design of the study, collection, analyses and interpretation of these data, writing of the manuscript, and decision to publish the results.

\section{References}

1. Oosting, S.J.; Udo, H.M.J.; Viets, T.C. Development of livestock production in the tropics: Farm and farmers' perspectives. Animal 2014, 8, 1238-1248. [CrossRef] [PubMed]

2. Winter, W.H.; Winks, L.; Seebeck, R.M. Sustaining productive pastures in the tropics 10. Forage and feeding systems for cattle. Trop. Grassl. 1991, 25, 145-152.

3. Hattersley, P.W. The distribution of C3 and C4 grasses in Australia in relation to climate. Oecologia 1983, 57, 113-128. [CrossRef]

4. Hunt, L.P.; Mcivor, J.G.; Grice, A.C.; Bray, S.G. Principles and guidelines for managing cattle grazing in the grazing lands of northern Australia: Stocking rates, pasture resting, prescribed fire, paddock size and water points: A review. Rangel. J. 2014, 36, 105-119. [CrossRef]

5. Edwards, E.J.; Smith, S.A. Phylogenetic analyses reveal the shady history of C4 grasses. Proc. Natl. Acad. Sci. USA 2010, 107, 2532-2537. [CrossRef]

6. Poppi, D.P.; Quigley, S.P.; Silva, T.A.C.C.; McLennan, S.R. Challenges of beef cattle production from tropical pastures. Rev. Bras. Zootec. 2018, 47, e20160419. [CrossRef]

7. Allison, C.D. Factors affecting forage intake by range ruminants: A review. J. Range Manag. 1985, 38, 305-311. [CrossRef]

8. McCown, R.L. The climatic potential for beef cattle production in tropical Australia: Part I-Simulating the annual cycle of liveweight change. Agric. Syst. 1981, 6, 303-317. [CrossRef]

9. Hill, J.O.; Coates, D.B.; Whitbread, A.M.; Clem, R.L.; Robertson, M.J.; Pengelly, B.C. Seasonal changes in pasture quality and diet selection and their relationship with liveweight gain of steers grazing tropical grass and grass-legume pastures in northern Australia. Anim. Prod. Sci. 2009, 49, 983-993. [CrossRef] 
10. Prudhomme, R.; Brunelle, T.; Dumas, P.; Le Moing, A.; Zhang, X. Assessing the impact of increased legume production in Europe on global agricultural emissions. Reg. Environ. Change 2020, 20, 91. [CrossRef]

11. Da Motta, E.A.M.; Dall-Agnol, M.; Rios, E.F.; Souza, C.H.L.; Weiler, R.L.; Brunes, A.P.; Simioni, C.; Rockenbach de Ávila, M.; Neto, D.; Felix, L.D.; et al. Agronomic performance of interspecific Paspalum hybrids under nitrogen fertilization or mixed with legumes. Agrosyst. Geosci. Environ. 2020, 3, e20127.

12. Castro-Montoya, J.M.; Dickhoefer, U. The nutritional value of tropical legume forages fed to ruminants as affected by their growth habit and fed form: A systematic review. Anim. Feed Sci. Technol. 2020, 269, 114641. [CrossRef]

13. Mannetje, L. Harry stobbs memorial lecture, 1994: Potential and prospects of legume-based pastures in the tropics. Trop. Grassl. 1997, 31, 81-94.

14. Coates, D.B.; Miller, C.P.; Hendricksen, R.E.; Jones, R.J. Stability and productivity of Stylosanthes pastures in Australia. II. Animal production from Stylosanthes pastures. Trop. Grassl. 1997, 31, 494-502.

15. Clem, R.L.; Hall, T.J. Persistence and productivity of tropical pasture legumes on three cracking clay soils (Vertisols) in northeastern Queensland. Aust. J. Exp. Agric. 1994, 34, 161-171. [CrossRef]

16. Pengelly, B.C.; Conway, M.J. Pastures on cropping soils: Which tropical pasture legume to use? Trop. Grassl. 2000, 34, 162-168.

17. Meat \& Livestock Australia (MLA). State of the Industry Report: The Australian Red Meat and Livestock Industry; Meat \& Livestock Australia (MLA): Sydney, Australia, 2019.

18. Soil Science Australia State Soils. Available online: https://www.soilscienceaustralia.org.au/about/about-soil/state-soil (accessed on 15 December 2020).

19. Weston, E.J.; Ellis, C.M.; Harbison, J. Assessment of the Agricultural and Pastoral Potential of Queensland; Queensland Department of Primary Industries: Brisbane, Australia, 1983; ISBN 0724221433.

20. Gardiner, C.P.; Swan, S.J. Abandoned pasture legumes offer potential economic and environmental benefits in semiarid clay soil rangelands. In Proceedings of the Australian Rangeland Society 15th Biennial Conference Proceedings, Charters Towers, Australia, 28 September-2 October 2008; p. 93.

21. Meat \& Livestock Australia (MLA) Legumes for Clay Soils. Available online: https://www.mla.com.au/download/finalreports? itemId=874 (accessed on 29 November 2020).

22. Vandermeulen, S.; Singh, S.; Ramírez-Restrepo, C.A.; Kinley, R.D.; Gardiner, C.P.; Holtum, J.A.M.; Hannah, I.; Bindelle, J. In vitro assessment of ruminal fermentation, digestibility and methane production of three species of Desmanthus for application in northern Australian grazing systems. Crop Pasture Sci. 2018, 69, 797-807. [CrossRef]

23. Suybeng, B.; Charmley, E.; Gardiner, C.P.; Malau-Aduli, B.S.; Malau-Aduli, A.E.O. Supplementing Northern Australian beef cattle with Desmanthus tropical legume reduces in-vivo methane emissions. Animals 2020, 10, 2097. [CrossRef] [PubMed]

24. Hill, J.O.; Clem, R.L.; Robertson, M.J.; Pengelly, B.C.; Whitbread, A. Beef production from tropical pasture legumes on cropping soils. In Proceedings of the 25th Biennial Conference of the Australian Society of Animal Production, Melbourne, Australia, 4-8 July 2004; CSIRO Publishing: Melbourne, Australia.

25. Gardiner, C.; Kempe, C.; Kempe, N.; Campbell, G.; Heitor, F.; Malau-Aduli, A.E.O.; Walker, G.; Suybeng, B.; Mwangi, F. Progardes Desmanthus: An update. In Proceedings of the Northern Beef Research Update Conference, Brisbane, Australia, 19-22 August 2019 ; p. 33.

26. Gardiner, C.; Parker, A. Steer liveweight gains on ProgardesTM Desmanthus/Buffel pastures in Queensland. In Proceedings of the 2nd Australian and New Zealand societies of animal production joint conference, Lincoln, New Zealand, 2-5 July 2012.

27. Marsetyo, D.R.; Rusiyantono, Y.; Syukur, S.H. The effect of supplementation of different legume leaves on feed intake, digestion and growth of Kacang goats given Mulato grass. J. Agric. Sci. Technol. 2017, 7, 117-122. [CrossRef]

28. Rangel, J.H.D.A.; Gardiner, C.P. Stimulation of wool growth by Desmanthus spp. as a supplement to a diet of Mitchell grass hay. Trop. Grassl. 2009, 43, 106-111.

29. Kanani, J.; Lukefahr, S.D.; Stanko, R.L. Evaluation of tropical forage legumes (Medicago sativa, Dolichos lablab, Leucaena leucocephala and Desmanthus bicornutus) for growing goats. Small Rumin. Res. 2006, 65, 1-7. [CrossRef]

30. Ndlovu, T.; Chimonyo, M.; Okoh, A.I.; Muchenje, V.; Dzama, K.; Raats, J.G. Assessing the nutritional status of beef cattle: Current practices and future prospects. Afr. J. Biotechnol. 2007, 6, 2727-2734.

31. Flier, J.; Maratos-Flier, E. Energy homeostasis and body weight. Curr. Biol. 2000, 10, R215-R217. [CrossRef]

32. National Research Council. Nutrient Requirements of Beef Cattle, 7th ed.; National Academies Press: Washington, DC, USA, 1996; ISBN 978-0-309-06934-2.

33. Nicholson, M.J.; Sayers, A.R. Repeatability, reproducibility and sequential use of condition scoring of Bos indicus cattle. Trop. Anim. Health Prod. 1987, 19, 127-135. [CrossRef]

34. Chester-Jones, H.; Fontenot, J.P.; Veit, H.P. Physiological and pathological effects of feeding high levels of magnesium to steers. J. Anim. Sci. 1990, 68, 4400-4413. [CrossRef]

35. Pambu-Gollah, R.; Cronjé, P.B.; Casey, N.H. An evaluation of the use of blood metabolite concentrations as indicators of nutritional status in free-ranging indigenous goats. S. Afr. J. Anim. Sci. 2000, 30, 115-120. [CrossRef]

36. Murillo-Ortiz, M.; Mellado-Bosque, M.; Herrera-Torres, E.; Reyes-Estrada, O.; Carrete-Carreón, F.O. Seasonal diet quality and metabolic profiles of steers grazing on Chihuahuan desert rangeland. Livestig. Sci. 2014, 165, 61-65. [CrossRef]

37. Abeni, F.; Bergoglio, G.; Masoero, G.; Terzano, G.M.; Allegrini, S. Plasma hormones and metabolites in Piedmontese cows during late pregnancy: Relationships with calf birth weight. J. Anim. Sci. 2004, 82, 438-444. [CrossRef] [PubMed] 
38. Movahedi, B.; Foroozandeh, A.D.; Shakeri, P. Effects of different forage sources as a free-choice provision on the performance, nutrient digestibility, selected blood metabolites and structural growth of Holstein dairy calves. J. Anim. Physiol. Anim. Nutr. 2017, 101, 293-301. [CrossRef] [PubMed]

39. Soder, K.J.; Sanderson, M.A.; Stack, J.L.; Muller, L.D. Intake and performance of lactating cows grazing diverse forage mixtures. J. Dairy Sci. 2006, 89, 2158-2167. [CrossRef]

40. Pembleton, K.G.; Hills, J.L.; Freeman, M.J.; McLaren, D.K.; French, M.; Rawnsley, R.P. More milk from forage: Milk production, blood metabolites, and forage intake of dairy cows grazing pasture mixtures and spatially adjacent monocultures. J. Dairy Sci. 2016, 99, 3512-3528. [CrossRef] [PubMed]

41. Ragni, M.; Colonna, M.A.; Lestingi, A.; Tarricone, S.; Giannico, F.; Marsico, G.; Facciolongo, A.M. Effects of protein sources on performance, carcass composition, blood parameters and meat quality in Charolais heifers. S. Afr. J. Anim. Sci. 2018, 48, 683-694. [CrossRef]

42. National Health and Medical Research Council. Australian Code of Practice for the Care and Use of Animals for Scientific Purposes, 8th ed.; National Health and Medical Research Council: Canberra, Australia, 2013; ISBN 1864965975.

43. Collins, J.; Gardiner, C.P.; Kempe, N.; Hannah, I. Successful pasture development at Cungelella: A grazier, a researcher and a seed company's perspective. In Proceedings of the Northern Beef Research Update Conference, Leichhardt Hotel, Rockhampton, Australia, 15-18 August 2016.

44. Gardiner, C.; Kempe, N.; Hannah, I.; Mcdonald, J. PROGARDESTM: A legume for tropical/subtropical semi-arid clay soils. Trop. Grassl. Forrajes Trop. 2013, 1, 78-80. [CrossRef]

45. Gardiner, C. Developing and commercializing new pasture legumes for clay soils in the semi-arid rangelands of northern Australia: The new Desmanthus cultivars JCU 1-5 and the Progardes story. In Tropical Forage Legumes. Harnessing the Potential of Desmanthus and Other Genera for Heavy Clay Soils; Lazier, J.R., Ahmad, N., Eds.; CABI: Boston, MA, USA, 2016 ; pp. $283-304$.

46. Miller, C.P.; Stockwell, T.G.H. Sustaining productive pastures in the tropics. 4. Augmenting native pasture with legumes. Trop. Grassl. 1991, 25, 98-103.

47. Tothill, J.C.; Hargreaves, J.; Jones, R. Botanal-A Comprehensive Sampling and Computing Procedure for Estimating Pasture Yield and Composition. 1. Field Sampling; CSIRO Division of Tropical Crops and Pastures: Queensland, Australia, 1992.

48. McDonald, C.K.; Corfield, J.P.; Hargreaves, J.N.G.; O’Toole, J.G. Botanal: A Comprehensive Sampling and Computing Procedure for Estimating Pasture Yield and Composition. 3. Field Recording Direct to Computer, 2nd ed.; CSIRO: Brisbane, Australia, 1996.

49. Stoddart, L.A. Range capacity determination. Ecology 1935, 16, 531-532.

50. Sweeney, R.A.; Rexroad, P.R. Comparison of LECO FP-228 "nitrogen determinator" with AOAC copper catalyst Kjeldahl method for crude protein. J. Assoc. Off. Anal. Chem. 1987, 70, 1028-1030. [CrossRef]

51. Van Soest, P.J.; Robertson, J.B.; Lewis, B.A. Methods for dietary fiber, neutral detergent fiber, and nonstarch polysaccharides in relation to animal nutrition. J. Dairy Sci. 1991, 74, 3583-3597. [CrossRef]

52. Goering, H.K.; Van Soest, P.J. Forage Fiber Analysis (Apparatus, Reagents, Procedures, and Some Applications); ARS-USDA: Washington, DC, USA, 1970.

53. Faichney, G.; White, G. Methods for the Analysis of Feeds Eaten by Ruminants; CSIRO: Melbourne, Australia, 1983 ; ISBN 0643035621.

54. Clarke, T.; Flinn, P.C.; McGowan, A. Low-cost pepsin-cellulase assays for prediction of digestibility of herbage. Grass Forage Sci. 1982, 37, 147-150. [CrossRef]

55. Commonwealth Scientific and Industrial Research Organisation. Nutrient Requirements of Domesticated Ruminants; CSIRO Publishing: Collingwood, Australia, 2007; ISBN 9780643092624.

56. Coates, D.B.; Dixon, R.M. Faecal near infrared reflectance spectroscopy (F.NIRS) measurements of non-grass proportions in the diet of cattle grazing tropical rangelands. Rangel. J. 2007, 29, 51-63. [CrossRef]

57. Dixon, R.M.; Coates, D.B. Diet quality and liveweight gain of steers grazing Leucaena-grass pasture estimated with faecal near infrared reflectance spectroscopy (F.NIRS). Aust. J. Exp. Agric. 2008, 48, 835-842. [CrossRef]

58. Coates, D.B. Improving Nutritional Management of Grazing Cattle: Improving Reliability of Faecal NIRS Calibration Equations; Meat \& Livestock Australia: North Sydney, Australia, 2004.

59. Coates, D.B.; Dixon, R.M. Development of near infrared analysis of faeces to estimate non-grass proportions in diets selected by cattle grazing tropical pastures. J. Near Infrared Spectrosc. 2008, 16, 471-480. [CrossRef]

60. Hacker, J.B.; Waite, R.B. Selecting buffel grass (Cenchrus ciliaris) with improved spring yield in subtropical Australia. Trop. Grassl. 2001, 35, 205-210.

61. Cowie, B.A.; Thornton, C.M.; Radford, B.J. The Brigalow catchment study: I. Overview of a 40-year study of the effects of land clearing in the brigalow bioregion of Australia. Soil Res. 2007, 45, 479. [CrossRef]

62. Gulwa, U.; Mgujulwa, N.; Beyene, S.T. Effect of grass-legume intercropping on dry matter yield and nutritive value of pastures in the Eastern Cape Province, South Africa. Univ. J. Agric. Res. 2017, 5, 355-362. [CrossRef]

63. Lüscher, A.; Suter, M.; Finn, J.; Collins, R.; Gastal, F. Quantification of the Effect of Legume Proportion in the Sward on Yield Advantage and Options to Keep Stable Legume Proportions (over Climatic Zones Relevant for Livestock Production). HAL Arch. Ouv. 2014, 7.3, 35.

64. Bork, E.W.; Gabruck, D.T.; McLeod, E.M.; Hall, L.M. Five-year forage dynamics arising from four legume-grass seed mixes. Agron. J. 2017, 109, 2789-2799. [CrossRef] 
65. Khatiwada, B.; Acharya, S.N.; Larney, F.J.; Lupwayi, N.Z.; Smith, E.G.; Islam, M.A.; Thomas, J.E. Benefits of mixed grass-legume pastures and pasture rejuvenation using bloat-free legumes in western Canada: A review. Can. J. Plant Sci. 2020, 100, 463-476. [CrossRef]

66. Thomas, R.J. Role of legumes in providing $\mathrm{N}$ for sustainable tropical pasture systems. In Developments in Plant and Soil Sciences; Ladha, J.K., Peoples, M.B., Eds.; Springer Science and Business Media, B.V.: Dordrecht, The Netherlands, 1995; Volume 65, pp. 103-118, ISBN 978-94-010-4029-7.

67. Thomas, R.J. The role of the legume in the nitrogen cycle of productive and sustainable pastures. Grass Forage Sci. 1992, 47, 133-142. [CrossRef]

68. Durmic, Z.; Ramírez-Restrepo, C.A.; Gardiner, C.; O’Neill, C.J.; Hussein, E.; Vercoe, P.E. Differences in the nutrient concentrations, in vitro methanogenic potential and other fermentative traits of tropical grasses and legumes for beef production systems in northern Australia. J. Sci. Food Agric. 2017, 97, 4075-4086. [CrossRef] [PubMed]

69. Hennessy, D.W.; Williamson, P.J.; Nolan, J.V.; Kempton, T.J.; Leng, R.A. The roles of energy- or protein-rich supplements in the subtropics for young cattle consuming basal diets that are low in digestible energy and protein. J. Agric. Sci. 1983, 100, 657-666. [CrossRef]

70. Leng, R.A. Factors affecting the utilization of 'poor-quality' forages by ruminants particularly under tropical conditions. Nutr. Res. Rev. 1990, 3, 277-303. [CrossRef] [PubMed]

71. Dove, H.; Mayes, R.W. Using n-alkanes and other plant wax components to estimate intake, digestibility and diet composition of grazing/browsing sheep and goats. Small Rumin. Res. 2005, 59, 123-139. [CrossRef]

72. Gordon, I.J. Animal-based techniques for grazing ecology research. Small Rumin. Res. 1995, 16, 203-214. [CrossRef]

73. Dove, H. Pasture and grazing animals-The interaction continues. Anim. Prod. Aust. 1998, 22, 3-13.

74. Bowen, M.K.; Chudleigh, F.; Buck, S.; Hopkins, K. Productivity and profitability of forage options for beef production in the subtropics of northern Australia. Anim. Prod. Sci. 2018, 58, 332-342. [CrossRef]

75. White, I.A.; Hunt, L.P.; Poppi, D.P.; Petty, S.R. Sampling requirements for predicting cattle diet quality using faecal near-infrared reflectance spectroscopy (F.NIRS) in heterogeneous tropical rangeland pastures. Rangel. J. 2010, 32, 435-441. [CrossRef]

76. Dixon, R.M.; Coates, D.B. The use of faecal NIRS to improve nutritional management of cattle in northern Australia. Recent Adv. Anim. Nutr. Aust. 2005, 15, 65-75.

77. Orr, D.; Evenson, C.; Jordan, D.; Bowly, P.; Lehane, K.; Cowan, D. Sheep productivity in an Astrebla grassland of south-west Queensland. Rangel. J. 1988, 10, 39-47. [CrossRef]

78. Holm, A.; Eliot, G. Seasonal changes in the nutritive value of some native pasture species in North-western Australia. Rangel. J. 1980, 2, 175-182. [CrossRef]

79. Hall, T. The nitrogen and phosphorus concentrations of some pasture species in the Dichanthium-Eulalia Grasslands of NorthWest Queensland. Rangel. J. 1981, 3, 67. [CrossRef]

80. Hersom, M.J.; Wettemann, R.P.; Krehbiel, C.R.; Horn, G.W.; Keisler, D.H. Effect of live weight gain of steers during winter grazing: III. Blood metabolites and hormones during feedlot finishing. J. Anim. Sci. 2004, 82, 2059-2068. [CrossRef]

81. Murillo, M.; Herrera, E.; Ruiz, O.; Reyes, O.; Carrete, F.O.; Gutierrez, H. Effect of supplemental corn dried distillers grains with solubles fed to beef steers grazing native rangeland during the forage dormant season. Asian Australas. J. Anim. Sci. 2015, 29, 666-673. [CrossRef] [PubMed]

82. Kaneko, J.J. Carbohydrate Metabolism and Its Diseases, 5th ed.; Kaneko, J., Harvey, J., Bruss, M., Eds.; Elsevier: San Diego, CA, USA, 1997; ISBN 978-0-12-396305-5.

83. Mitruka, B.M.; Rawnsley, H.M. Clinical Biochemical and Hematological Reference Values in Normal Experimental Animals; Masson Publishing USA Inc.: New York, USA, 1977; ISBN 9780893520663.

84. Asano, K.; Ishida, M.; Ishida, M. Effects of inclusion levels of pelleted silvergrass (Miscanthus sinensis Andress.) in the diet on digestibility, chewing activity, ruminal fermentation and blood metabolites in breeding Japanese Black cows. Anim. Sci. J. 2017, 88, 468-475. [CrossRef]

85. Beeby, J.M.; Haresign, W.; Swan, H. Endogenous hormone and metabolite concentrations in different breeds of beef steer on two systems of production. Anim. Prod. 1988, 47, 231-244. [CrossRef]

86. Benedet, A.; Manuelian, C.L.; Zidi, A.; Penasa, M.; De Marchi, M. Invited review: $\beta$-hydroxybutyrate concentration in blood and milk and its associations with cow performance. Animal 2019, 13, 1676-1689. [CrossRef] [PubMed]

87. Braun, J.-P.; Lefebvre, H.P. Kidney function and damage. In Clinical Biochemistry of Domestic Animals; Kaneko, J.J., Harvey, J.W., Bruss, M.L., Eds.; Elsevier: Amsterdam, The Netherlands, 2008; pp. 485-528, ISBN 9780123704917.

88. Grünwaldt, E.G.; Guevara, J.C.; Estévez, O.R.; Vicente, A.; Rousselle, H.; Alcuten, N.; Aguerregaray, D.; Stasi, C.R. Biochemical and haematological measurements in beef cattle in Mendoza plain rangelands (Argentina). Trop. Anim. Health Prod. 2005, 37, 527-540. [CrossRef]

89. Otto, F.; Vilela, F.; Harun, M.; Taylor, G.; Baggasse, P.; Bogin, E. Biochemical blood profile of Angoni catle in Mozambique. Isr. J. Vet. Med. 2000, 55, 1-9.

90. Agenas, S.; Heath, M.; Nixon, R.; Wilkinson, J.; Phillips, C. Indicators of undernutrition in cattle. Anim. Welf. 2006, 15, 149-160.

91. Issi, M.; Gül, Y.; Başbuğ, O. Evaluation of renal and hepatic functions in cattle with subclinical and clinical ketosis. Turk. J. Vet. Anim. Sci. 2016, 40, 47-52. [CrossRef] 
92. Ngo, T. The Effects of Diet Preference on Feed Intake, Digestibility and Nitrogen Balance of Sheep Given Flinders Grass (Iseilema spp.) Hay and/or Desmanthus Leptophyllus ad Libitum. Master's Thesis, James Cook University, Townsville, Australia, 2017.

93. Aoetpah, A.; Gardiner, C.; Gummow, B.; Walker, G. Growth and eye muscle area of cross-bred Boer goats fed Desmanthus cultivar JCU 1 hay. In Proceedings of the 32nd Biennial Conference of the Australian Society of Animal Production, Wagga Wagga, Australia, 2-4 July 2018.

94. Radrizzani, A.; Nasca, J.A. The effect of Leucaena leucocephala on beef production and its toxicity in the Chaco Region of Argentina. Trop. Grassl.-Forrajes Trop. 2014, 2, 127-129. [CrossRef]

95. Castro-Montoya, J.; Dickhoefer, U. Effects of tropical legume silages on intake, digestibility and performance in large and small ruminants: A review. Grass Forage Sci. 2018, 73, 26-39. [CrossRef]

96. Cheffins, R. Nutritional and Managerial Opportunities for Meeting Beef Markets. Information Series QI 96112; Department of Primary Industries Queensland Meat Research Corporation: Brisbane, Australia, 1996; ISBN 0724266909 (pbk.).

97. Rubanza, C.D.K.; Shem, M.N.; Otsyina, R.; Fujihara, T. Performance of Zebu steers grazing on western Tanzania native forages supplemented with Leucaena leucocephala leaf meal. Agrofor. Syst. 2005, 65, 165-174. [CrossRef]

98. Pen, M.; Savage, D.B.; Nolan, J.V.; Seng, M. Effect of Stylosanthes guianensis supplementation on intake and nitrogen metabolism of Bos indicus cattle offered a basal diet of mixed rice straw and tropical grass. Anim. Prod. Sci. 2013, 53, 453-457. [CrossRef]

99. Bowman, J.G.P.; Sowell, B.F.; Paterson, J.A. Liquid supplementation for ruminants fed low-quality forage diets: A review. Anim. Feed Sci. Technol. 1995, 55, 105-138. [CrossRef]

100. Detmann, E.; Valente, É.E.L.; Batista, E.D.; Huhtanen, P. An evaluation of the performance and efficiency of nitrogen utilization in cattle fed tropical grass pastures with supplementation. Livestig. Sci. 2014, 162, 141-153. [CrossRef]

101. McCown, R.L.; McLean, R.W. An analysis of cattle live-weight changes on tropical grass pasture during the dry and early wet seasons in northern Australia: 2. Relations to trends in the pasture, diet and grazing behaviour. J. Agric. Sci. 1983, 101, 17-24. [CrossRef]

102. Schatz, T.; Ffoulkes, D.; Shotton, P.; Hearnden, M. Effect of high-intensity rotational grazing on the growth of cattle grazing buffel pasture in the Northern Territory and on soil carbon sequestration. Anim. Prod. Sci. 2020, 1814-1821. [CrossRef]

103. Dixon, R.M.; Shotton, P.; Mayer, R. Diets selected and growth of steers grazing buffel grass (Cenchrus ciliaris cv. Gayndah)-Centro (Centrosema brasilianum cv. Oolloo) pastures in a seasonally dry tropical environment. Anim. Prod. Sci. 2020, 60, 1459-1468. [CrossRef]

104. Ash, A.J.; McIvor, J.G.; Corfield, J.P.; Winter, W.H. How land condition alters plant-animal relationships in Australia's tropical rangelands. Agric. Ecosyst. Environ. 1995, 56, 77-92. [CrossRef]

105. Clements, R.J. Pastures for prosperity. 3. The future for new tropical pasture plants. Trop. Grassl. 1996, 30, 31-46.

106. Brandão, R.K.C.; de Carvalho, G.; Silva, R.; Dias, D.; Mendes, F.; Lins, T.; Pereira, M.; Guimarães, J.; Tosto, M.; Rufino, L.; et al. Correlation between production performance and feeding behavior of steers on pasture during the rainy-dry transition period. Trop. Anim. Health Prod. 2018, 50, 105-111. [CrossRef] [PubMed]

107. Drouillard, J.S.; Kuhl, G.L. Effects of previous grazing nutrition and management on feedlot performance of cattle. J. Anim. Sci. 1999, 77, 136-146. [CrossRef] [PubMed] 